\title{
Medical students' viewpoints towards team motivation, enjoyment, and participation at Tehran University: The role of demographic
} features

\author{
Amir Hossein Mohammad Davoudi ${ }^{1}$, Ashraf Sadat Parpouchi ${ }^{2}$, Aghdas Nikooravesh ${ }^{3}$ \\ ${ }^{1,2}$ Department of Management, College of Human Science, Saveh Branch, Islamic Azad University, Saveh, Iran \\ ${ }^{3}$ Department of Management, College of Human Science, Garmsar Branch, Islamic Azad University, Garmsar, \\ Iran
}

\begin{tabular}{l}
\hline \\
Keywords: \\
Motivation, Team \\
Enjoyment, Team \\
Participation \\
\\
\hline Received \\
7 October 2015 \\
Received in revised form \\
10 April 2016 \\
Accepted \\
10 April 2016 \\
\end{tabular}

Correspondence:

af.parpoochi@gmail.com

\section{Abstract}

\begin{abstract}
This study was conducted to compare the medical students' viewpoints towards team motivation, enjoyment, and participation at Tehran University considering demographic features. The statistical population of this research consisted of all medical students of Tehran University from 2011 up to now and then 326 of students were selected using Morgan table and simple accidental sampling method. To gather data, a researcher-made questionnaire consisting of three sections including team motivation, team enjoyment, team participation was distributed among the participants. To estimate the reliability of each section, Cronbach's alpha coefficient was used. Independent t-test was performed to compare whether two independent groups (female and male) had different average values. In order to determine the differences between research variables among medical students from gander and field of study aspects, unilaterally variance analysis was used. The equality of two groups' variances was determined via Loon test then the assumption of homogeneity of variances was accepted. The results revealed that there were not significant differences in the mean scores of medical students of Tehran University regarding team motivation, team enjoyment, and team participation from gender and field of study aspects.
\end{abstract}

(C)AIMI Journals

\section{Introduction}

Motivation is seen as a process that keeps a targeted activity motivated and in progress. Motivation is a process rather than a product. Since we cannot observe motivation directly, we should deduce it from some behaviors and the environment in which the students act such as 
homework selection, effort, and resistance (Najmi \& Feizi, 2011). There are many factors that can affect on students' motivation such as their needs, interests, values, attitudes, individual approaches, and requirements.

The most important factor that influence on students' motivation is their needs. When someone needs something, it means for an individual to be participating in that activity and meet his/her own needs. Actually, types of needs have a large role in determining human behavior. The next factor is interest which means tendency to give attention and being interested in doing an activity. Value applies to material value as well as to spiritual value that is designated to someone or something. It is usually necessary to meet students' needs and accomplish their goals. Attitude implies to an inner compatible or incompatible feeling toward someone, something, or an affair (Parsa, 1997). Individual approach also refers to the learning environment, teacher, and subjects of study. Requirements show the students' basic needs and wants in the time of learning process.

Motivation is divided into two types including intrinsic (internal) motivation and extrinsic (external) motivation. Intrinsic motivation seems to mean doing an affair for the sake of that affair and enjoyment. When there is an opportunity for students to select, it gets them motivated to learn more because they can challenge and compete with each other and be rewarded by knowledge and information. There are two kinds of intrinsic motivation, namely self-determined or individual selection and optimal experience or flourish. Extrinsic motivation refers to motivation that comes from outside an individual. It means doing an affair for achieving something except that affair. This kind of motivation is influenced by incentive learning such as rewards and punishments. For example, a student may try a lot to get good grades, many of effective learning techniques are found on the basis of motivational excitation of students and their eagerness to learn (Biabangard, 2004, 2005). Enjoyment is the state or feeling of pleasure and satisfaction which is obtained from doing an enjoyable affair

Team enjoyment is considered as an emotional variable that is an important affair in ethology of learners. Davis, Bagozzi, and Warshaw (1992) defined enjoyment as providing a delightful and enjoyable learning environment for learners. Enjoyment is defined as positive emotional reactions that are the reflection of general feelings such as happiness, delightfulness, liking, and entertainment; therefore, students feel the whole learning experience pleasantly. Team enjoyment is an important concept in learning because it gives cognitive absorption to the lessons. Agarwal and Krahanna (2000) defined cognitive absorption as a deep involvement in the classroom that affects interaction and behavioral goals. The development of this concept in cognitive domain leads to the deeper involvement of educational subjects and results in promoting learning level.

Learning enjoyment is achieved through participation and paying attention to subjects. There are some factors that encourage students to enjoy their learning including the relevance of what students learn in class and their real life, meaningful learning, intellectual precipitation, group discussion, subject challenges, active learning, unexpected programs, life guidance, studying interesting book, providing pleasant situations, learning for life, and educational digression reforms. Participation means application of educational-experimental techniques in a group of learners who have different genders, races, and educational abilities and regulate their participatory learning activities in accordance with the learning standards and other school 
curriculums or educational situations. Participation feature among learners of a group makes them feel greater responsibility toward group or team objectives and goals. The most important feature of participatory learning is the time that learners help each other to compete with and surpass the students of rivals (opponent group). When interaction patterns of team members and their participation become the objective of a strong collaborative team spirit can be created.

Some researchers believe that having a strong collaborative spirit and working orientation is independent of achieving agreements about results. Team-oriented work makes them to be more certain of their own roles and evaluations. Additionally, team participation is a set of actions that increases the feelings of responsibility and influences on members' decision making through entrusting authority in different levels of the organization and allows them to feel connected, attached, and part of the organization (Mirkamali, 1999).

\section{The Review of Literature}

Roshan Milani et al. (2012) investigated the educational motivation and its relationship with personal and academic achievement of medical students in basic sciences in Urmia University. They found out that girls had significantly higher motivation as compared to boys. Additionally, most of the students had a medium to good level motivation to learn medical sciences, and extrinsic motivational components acquired more scores than intrinsic ones. Yousefi, Ghassemi, and Firouzniya (2009) evaluated the relationship between educational motivation and academic achievement in medical students of Isfahan University. Their study revealed that there is a positive and meaningful relationship between educational motivation and academic achievement and boys had a greater tendency to compete than girls. Kusurkar (2012) studied the medical students' motivation and their learning results and observed that intrinsic motivation is significantly associated with good educational performance and deep study strategy.

Motivation as a dependent variable appears to be affected by age, puberty, gender, and field of study. Students' intrinsic motivation increase via independence and receiving feedback and emotional support. Gooch (2012) in his study investigated the effects of active learning on students' enjoyment. He found out that the active learning had a remarkable influence on students' pleasure and their learning. Some other researchers explored the interaction between teenage students and science and pointed to students' interest and excitement in learning their interested subject knowledge. Interest in the subject matter and course enjoyment re factors that can improve the learning process and promote students' motivation (Davis, 1993). Motaei (2014) explored the effect of cooperative learning process on general English achievement of students learning in Kermanshah Islamic Azad University. The results of study revealed that there was a significant difference in the performance of learning groups and traditional students had better performances. Sadati et al. (2013) examined the effect of cooperation teaching based on students' active participation on learning in paramedical faculty of Alborz University of medical sciences. They found out that there was a significant difference among mean scores of two groups and they concluded that students' active participation is an effective method in improving students' learning level and achievement. 


\section{Research Questions}

In line with the discussion above, the following research questions were formulated:

- How much motivation can be seen among medical students of Tehran University from gender aspect?

- How much team enjoyment can be seen among medical students of Tehran University from gender aspect?

- How much team participation can be seen among medical students of Tehran University from gender aspect?

- How much motivation can be seen among medical students of Tehran University from age aspect?

- How much team enjoyment can be seen among medical students of Tehran University from age aspect?

- How much team participation can be seen among medical students of Tehran University from age aspect?

- How much motivation can be seen among medical students of Tehran University from field of study aspect?

- How much team enjoyment can be seen among medical students of Tehran University from field of study aspect?

- How much team participation can be seen among medical students of Tehran University from field of study aspect?

\section{Method}

The statistical population of this study consisted of 1272 of medical students of Tehran University from 1390. Simple accidental sampling or convenience sampling method was applied. The statistical sample considering Morgan table was 326 individuals. A researchermade questionnaire including three sections was used as a data collection instrument. To assess the reliability of each section, Cronbach's alpha coefficient was used. The reliability of each section was 7.9, 8.7, and 7.8, respectively. Content validity of this questionnaire has been confirmed by specialists in this field. The independent t-test was used to compare the means of two independent groups including female and male students from gender and field of study aspects. To compare three research variables including team motivation, enjoyment, and participation among medical students of Tehran University from gander aspect, unilaterally variance analysis was used. According to the test for equality of variances (Loon test) and the significant level of each section which was greater than 0.05 , it could be stated that the variances were equal. The assumption of homogeneity of variance via equivalence in two mentioned groups was accepted considering obtained information.

\section{Results}

In order to answer first three research questions, an independent t-test was run to compare the mean scores of two independent groups including female and male medical students. Table 1 shows the results of independent t-test for comparing the mean scores of medical students in two independent groups from gender aspect. According Table 1, the meaningful level of t-test 
for three variables including team motivation, team enjoyment, and team participation was higher than $5\left(\mathrm{~T}_{\text {Team Motivation }}=62 / 1, \mathrm{P}_{\text {Team Motivation }}=107 ; \mathrm{T}_{\text {Team Enjoyment }}=3 / 1, \mathrm{P}_{\text {Team Enjoyment }}=\right.$ 306; $\mathrm{T}_{\text {Team Participation }}=67 / 7, \mathrm{P}$ Team Participation $\left.=503\right)$ respectively. There were not significant differences in the mean scores of medical students for each variable namely team motivation, team enjoyment, and team participation from gender aspect; therefore, the first three assumptions were not rejected.

Table 1

Results of Independent T- Test for Comparing Mean Scores of Medical Students from Gender Aspect

\begin{tabular}{|c|c|c|c|c|c|c|}
\hline Variables & Group Average & $\begin{array}{l}\text { Standard } \\
\text { Deviation }\end{array}$ & $\begin{array}{c}\text { Average } \\
\text { Difference }\end{array}$ & Observed T & $\begin{array}{c}\text { Freedom } \\
\text { Degree }\end{array}$ & Meaningful Level \\
\hline \multirow{2}{*}{$\begin{array}{c}\text { Team } \\
\text { Motivation }\end{array}$} & Boy $92 / 25$ & 47.6 & \multirow[t]{2}{*}{14.1} & \multirow[t]{2}{*}{62.1} & \multirow[t]{2}{*}{321} & \multirow[t]{2}{*}{107} \\
\hline & Girl 78/24 & 22.6 & & & & \\
\hline \multirow{2}{*}{$\begin{array}{c}\text { Team } \\
\text { Enjoyment }\end{array}$} & Boy $72 / 19$ & 7.5 & \multirow[t]{2}{*}{59} & \multirow[t]{2}{*}{3.1} & \multirow[t]{2}{*}{321} & \multirow[t]{2}{*}{306} \\
\hline & Girl 13/19 & 21.5 & & & & \\
\hline \multirow{2}{*}{$\begin{array}{c}\text { Team } \\
\text { Participation }\end{array}$} & Boy 71/14 & 90.2 & \multirow[t]{2}{*}{22} & \multirow[t]{2}{*}{67} & \multirow[t]{2}{*}{380} & \multirow[t]{2}{*}{503} \\
\hline & Girl 49/14 & 83.2 & & & & \\
\hline
\end{tabular}

Then, a Loon test was run to determine the equality of variances for two groups. Table 2 depicts the Loon test results for investigating the equality of variances. According Table 2, the assumption of equality of variances was accepted for first three research questions.

Table 2

Loon Test Results for Investigating the Equality of Variances for First Three Research Questions

\begin{tabular}{lcc}
\hline Variables & F & Sig \\
\hline Team Motivation & 395.0 & 530.0 \\
Team Enjoyment & 123.0 & 726.0 \\
Team Participation & 036.0 & 849.0 \\
\hline
\end{tabular}

To answer second three research questions, medical students were divided into three groups considering their age (20 years old or less, 21 to 24 years old, 25 years old or more) and then unilaterally variance analysis was used. Table 3 presents the results of equality of variances for these age groups through running Loon test. The assumption of homogeneity of variance via equivalence in three mentioned groups was accepted considering obtained information.

Table 3

Loon Test Results for Investigating the Equality of Variances for Second Three Research Questions

\begin{tabular}{lcc}
\hline Variables & Df1-Df2 & Sig. \\
\hline Team Motivation & $24.2-2323$ & 105 \\
Team Enjoyment & $3.2-2323$ & 133 \\
Team Participation & $43.1-2323$ & 153 \\
\hline
\end{tabular}

Table 4 shows the results of unilaterally variance analysis for comparing the mean scores of groups according to their age aspect. The meaningful level for each three variables including team motivation, team enjoyment, and team participation is higher than 5 ( $\mathrm{T}_{\text {Team Motivation }}=2 / 1$, 
$\mathrm{P}$ Team Motivation $=363 ; \mathrm{T}_{\text {Team Enjoyment }}=356, \mathrm{P}$ Team Enjoyment $=701 ; \mathrm{T}_{\text {Team Participation }}=356, \mathrm{P}$ Team Participation $=701$ ) respectively.

Table 4

Unilaterally Variance Analysis Results for Comparing the Mean Scores of Medical Students from their Age Aspect

\begin{tabular}{|c|c|c|c|c|c|c|}
\hline Variables & $\begin{array}{l}\text { Resource of } \\
\text { Changes }\end{array}$ & $\begin{array}{l}\text { Sum of Square } \\
\text { Roots }\end{array}$ & $\begin{array}{l}\text { Freedom } \\
\text { Degree }\end{array}$ & $\begin{array}{l}\text { Average of } \\
\text { Square Roots }\end{array}$ & $\mathrm{F}$ & $\begin{array}{l}\text { Meaningful } \\
\text { Level }\end{array}$ \\
\hline \multirow[t]{3}{*}{ Team Motivation } & Among Groups & $56 / 82$ & 2 & $28 / 41$ & $2 / 1$ & 363 \\
\hline & In the Groups & $32 / 23$ & 323 & $66 / 40$ & & \\
\hline & Total & $88 / 13$ & 325 & & & \\
\hline \multirow[t]{3}{*}{ Team Enjoyment } & Among Groups & $76 / 18$ & 2 & $38 / 9$ & 356 & 701 \\
\hline & In the Groups & $40 / 58$ & 323 & $38 / 26$ & & \\
\hline & Total & $16 / 58$ & 325 & & & \\
\hline \multirow[t]{3}{*}{ Team Participation } & Among Groups & $58 / 37$ & 2 & $79 / 18$ & $32 / 2$ & 100 \\
\hline & In the Groups & $2 / 26$ & 323 & $9 / 8$ & & \\
\hline & Total & $10 / 26$ & 325 & & & \\
\hline
\end{tabular}

Table 5 shows the results of independent t-test for comparing the mean scores of medical students based on three variables including team motivation, team enjoyment, and team participation from their field of study aspect. Therefore, there were not any significant differences in the mean scores of medical students of Tehran University regarding team motivation, team enjoyment, and team participation from field of study aspect by considering their meaningful levels which were higher than 5 .

Table 5

The Results of Independent T-Test for Comparing Mean Scores of Medical Students from their Field of Study Aspect

\begin{tabular}{ccccccc}
\hline Variables & Group & Average & $\begin{array}{c}\text { Standard } \\
\text { Deviation }\end{array}$ & $\begin{array}{c}\text { Average } \\
\text { Difference }\end{array}$ & $\begin{array}{c}\text { Observed T } \\
\text { Freedom } \\
\text { Degree }\end{array}$ & $\begin{array}{c}\text { Meaningful } \\
\text { Level }\end{array}$ \\
\hline $\begin{array}{c}\text { Team } \\
\text { Motivation }\end{array}$ & Medicine & $31 / 25$ & $41 / 6$ & 12 & 12 & 323 \\
$\begin{array}{c}\text { Team } \\
\text { Enjoyment }\end{array}$ & Dentistry & $19 / 25$ & $6 / 6$ & & 404 & 323 \\
\hline $\begin{array}{c}\text { Team } \\
\text { Participation }\end{array}$ & Dedicine & $43 / 19$ & $16 / 5$ & 33 & & 390 \\
\hline
\end{tabular}

\section{Discussion and Conclusion}

This study was conducted to compare the medical students' viewpoints towards team motivation, enjoyment, and participation at Tehran University considering demographic features. According to the obtained results, there were not significant differences in the mean scores of medical students of Tehran University from their gender aspect. The results were congruent with Roshan Milani (2012) and Yousefi et al. (2009) who confirmed motivation has positive effect on students' viewpoint and this component acted differently among male and female students and male students were more motivated to compete than female ones. This study also revealed that there were not significant differences in the mean scores of medical students of Tehran University from their age aspect. This confirmed the findings by Kusurkar 
(2012) and Kusurkar, Ten Cate, Van Asperen, and Croiset (2011) who stated that motivation is a dependent variable and considerably is influenced by age, puberty, gender, and field of study. Regarding third three research questions, the results indicated that there were not significant differences in the mean scores of medical students of Tehran University from their field of study aspect. These results supported the findings of several previous studies such as Gooch (2012) and Sadati et al. (2013) proposing the effect of students participation in learning process helped in promoting their learning level and acquisition. If students choose their field of study base on their interests, their learning processes would also improve. It means that they put their heart and soul in order to do their best. Also, interest plays a key role in influencing students learning and finding enjoyment in their learning.

\section{References}

Agarwal, R., \&Krahanna, E. (2000).Time flies when you're having fun: Cognitive absorption and beliefs about information technology usage. MIS Quarterly, 24(4), 665-694.

Biabangard, E. (2005). The relationship between selfesteem, achievement motivation, and academic achievement of high school students in Tehran. Psychological Studies, 1(4/5), 131-144.

Biabangard, E. (2004). Methods of boosting self-esteem in children and teenagers. Tehran Parent Teacher Societies, 7, 52-68.

Davis, B. G. (1993). Motivating students: Tools for teaching. San Francisco: Jossey-Bass.

Davis, F. D., Bagozzi, R. P., \& Warshaw, P. R. (1992). Extrinsic and intrinsic motivation to use computers in the workplace. Journal of Applied Social Psychology, 22(14), 1111- 1132.

Gooch, M.M. (2012). Effects of active learning on students' enjoyment and content retention during Ecology field trips. Poster session presented at the meeting of Center for the Integration of Research, Teaching, and Learning, Otto, NC. (CIRTL) virtual Teaching as Research poster session (poster)

Kusurkar, R. (2012). Motivation in medical students: A PhD thesis report. Perspectives on Medical Education, 1(3), $155-157$.

Kusurkar, R. A., Ten Cate, T. J., Van Asperen, M., \& Croiset, G. (2011). Motivation as an independent and a dependent variable in medical education: A review of the literature. Medical Teacher, 33(5), 242-262.

Mirkamali, M. (1999). Leadership and management of the education $\left(5^{\text {th }}\right.$ ed.). Tehran: Sitron Publication.

Motaei, B. (2014). On the effect of cooperative learning on general english achievement of Kermanshah Islamic Azad University students. Procedia - Social \& Behavioral Sciences 98, 1249-1254.

Najmi, B., \& Feizi, A. (2011). Investigate the structural relationship between family functioning and self-esteem with academic achievement in high school girls. Quarterly Journal of Research modern psychology, 6,103-126.

Parsa, M. (1997). Psychology of motivation and emotion. Tehran: Sokhan Publications.

Roshan Milani, S.H.,Aghaee Monavar, E.,Kheradmand, F., Sabori, E., Mikaeeli, P., Masoudi, S., \& Motezaker, M. (2012). Study of motivation and its relationship with personal and academic achievement of medical students in basic sciences. Urmia University of Medical Sciences Journal of Nursing and Midwifery Faculty Urmia University of Medical Sciences, 5(34), 357-366.

Sadati, L., Pazouki, A., Golchin, E., Mehdizadehkashi, A., Pishgaroudsari, M., \& Tamannaie, Z. (2013). The effect of cooperative teaching based on students' active participation on learning level in the paramedical faculty of Alborz University of Medical Sciences. Biannual Journal of Medical Education, 1(2), 46-52.

Yousefi, A., Ghassemi, G., Firouzniya, S. (2009). The relationship between motivation education and academic achievement in medical students Isfahan University of medical sciences. Iranian Journal of Medical Education, 9(1), 79-84. 